International Journal of Engineering \& Technology, $7(4.33)(2018)$ 157-160
International Journal of Engineering \& Technology
SPC
Website: www.sciencepubco.com/index.php/IJET
Research paper

\title{
Utilizing Web Based Learning as 21st Century Learning Media for Vocational Education
}

\author{
Ervina Dika Tria Puspitasari ${ }^{1 *}$, Herman Dwi Surjono², Asnul Dahar Minghat ${ }^{3}$ \\ ${ }^{1}$ Vocational and Technology Education, Postgraduate Program, Yogyakarta State University, Indonesia \\ ${ }^{2}$ Instructional Technology, Postgraduate Program, Yogyakarta State University, Indonesia \\ ${ }^{3}$ Razak Faculty of Technology and Informatics, University of Technology Malaysia, Malaysia \\ *Corresponding author E-mail: ervinadikatria@gmail.com
}

\begin{abstract}
This study examines the development of information technology that focuses on the use of web based learning as a learning medium in the world of vocational education. Web-based learning provides convenience for students in learning activities such as increasing productivity, flexible and interactive. The results obtained from several literature studies from journal articles, opinion papers, conceptual papers, etc. were analyzed for content related to the use of web based learning in the world of vocational education. The result of the literature review in this paper is that E-learning is a learning process that is poured through internet technology, with the principle of simple, personal, and fast need to be considered. Therefore, the principles and communication of learning need to be designed like conventional learning. The need for developing the right e-learning learning model according to needs. Web base learning is a learning model that requires technological tools, especially information technology such as computers and internet access. In practice, web base learning utilizes internet facilities as a medium for delivering information (material) learning such as websites, e-mail, mailing lists, and news groups. The planned use of web-based learning technology has proven to provide a significant contribution to the world of education, especially for vocational education that requires students to think critically. In implementing web based learning, there are several factors that need to be considered such as supporting facilities and infrastructure, users (students as users and teachers/lecturers/experts as material presenter), readiness of online materials and costs.
\end{abstract}

Keywords: E-learning; Web Based Learning; Learning Media; Vocational Education

\section{Introduction}

The development of information technology is very rapid, not least in Indonesia. The development of technology and information is widely used to support and support human activities. According to existing sources, internet users in the world reach to the figure of 3.8 billion with penetration of $51 \%$ of the total population in the world [1]. Whereas, in Indonesia that internet users are more than $50 \%$ or around 143 million people have been connected to the internet network throughout 2017 [2]. This clearly indicates that there have been changes in lifestyle and the shift in the conventional model to modern (technology-based). Technological developments also affect activities in the world of education, especially in vocational education. The presence of Information Technology is one of the innovations of the learning model in the education world in the 21 st century. All literacy can be obtained through the internet. The use of information technology through the internet in the form of web-based learning media which is one form of e-learning developed in the $21 \mathrm{st}$ century era in welcoming the era of technological disruption in the industrial revolution 4.0. Rapidly, developing technology has flexible, interactive and unlimited properties, both in terms of space and time. Thus, the presence of technological development is one alternative for effective, efficient and superior learning media.
The use of media in 21st century learning is closely related to information technology, which is a supporting material for educators in the development of learning media and refers to critical thinking of students. The process of shifting the teaching paradigm, from teaching to learning, from learning to research has encouraged educators and students to balance the learning paradigm shift. The rapid development of computers requires educators to optimize applications and their functions in the field of education [3].

One of the uses of Web Based Learning (WBL) in the world of vocational education is the use of e-learning in the web-based learning process. E-learning is a computer technology equipment that is used to improve the learning and teaching process [4]. Elearning does not mean replacing the classical learning system practiced, but strengthens the learning model through enriching information about the substance of content and the development of educational technology.

Some characteristics of e-learning learning according to [5] are (1) e-learning is a form of learning that emphasizes the delivery of information, communication, education on the delivery of communication, information, training online; (2) The capacity of learning is very varied, depending on the form of content and the tools for delivering information on learning messages and learning styles. Content is well packaged and supported by information delivery tools and learning styles in a harmonious manner, so this learning capacity will be better which in turn will provide good results; (3) e-learning namely is a communication media that is 
effective, fast and credible, encompasses a large area, large class or small class, anytime and anywhere, building a community, improving student learning [6].

Rapid technological development requires a concept of teaching and learning that is supported by information technology. The concept that brings the influence of interactive learning methods into digital form, both multimedia content and the system. The concept of technology today has achieved rapid alignment so that it requires human resources who are ready and fit to use in utilizing these technological developments. The process of paradigm change occurs in shifting learning occurs because of the influence of the development of information technology on learning. Obtained from educational institutions and training institutions that are currently still in carrying out conventional concepts in providing learning materials. The concept of advance is faced with limited funds, time, and classroom facilities which ultimately weigh on the object being taught. But, in this era, not a few who have switched because of the shift and influence of the learning paradigm from teaching to learning.

E-learning is very potential to make the learning process more effective because the opportunities for students to interact with educators or teachers as well as learning materials are more widely open. Students can communicate with teachers with a more flexible time. Although, open use of communication can be closed between students and teachers or even together through bulletin boards [7]. Communication on e-learning is chosen, simultaneously or not. Through e-learning, students are allowed to remain able to study even if they are not physically present in the classroom. Learning activities become very flexible because they can be adjusted to the availability of time for students.

E-learning facilitates interaction between students and subject matter. Likewise, the interaction between students and lecturers / teachers / instructors and among students. Students can share information or opinions about various matters relating to the lesson or the need for self-development of students. Teachers / instructors / experts can place learning materials and tasks that must be done by students in certain places on the web to be accessed by students. Therefore, web based learning is effectively used as a learning medium in the 21 st century.

\section{Literature Review}

\subsection{Information and Technology Development}

The development of information technology development and the rapid growth of telecommunications in Indonesia, the use and utilization of information technology is an indication of the growth of technological progress of a nation and country. Therefore, the development of information technology and increased use are needed to improve competitiveness, especially in the field of vocational education. The world of work currently requires individuals who can form new skills, individuals who always want to learn new knowledge, gain new concepts and new theories in the field of technology. Therefore, they can transform into an individual who is more enthusiastic in facing technological developments and can reduce fear in individuals and society towards the field of technology [8].

The internet has expanded rapidly in human life. The use of technology needs to be utilized in the field of education. Technology in the world of vocational education is absolutely necessary because it can trigger the acceleration of learning. The latest information spread is easy to access via the internet. The growth of the internet is an undeniable reality as the real form of interactive learning revolution begins to grow rapidly with the ability to communicate information faster and flexibly

\subsection{1st Century Learning}

The development of education in the 21 st century is marked by progress and demands, namely the use of technology. The $21 \mathrm{st}$ century can replace human resources with technological sophistication. In this era of globalization, everything has become easier and more practical. This is indicated by the application of application technology that provides needs and facilitates human survival. In the world of education, it is very influential on students' behavior and way of thinking. With the facilities offered, it becomes a separate demand for the school and students to face the demands of these developments. Technological progress requires students to think more critically, creatively, innovatively and collaboratively. Critical thinking is one of the thinking skills of Higher Order Thinking Skills (HOTS), apart from being required to think critically, students must also be able to solve problems as well as reflective thinking. In [9] explained that critical thinking is a reflective thinking skill and defines it as a continuous active consideration. Critical thinking can be said as a person's ability to analyze an idea by analyzing logical reasoning.

\subsection{E-learning}

E-learning is electronic technology-based learning as a learning technology revolution. As a whole, e-learning can be defined as an effort to connect students with learning resources that are physically separated by distance but can communicate with each other or interact directly (synchronous) and indirect (asynchronous) [10-11] using technology like the internet. From the description of the definition of e-learning is a flexible learning media, so that the characteristics can be changed according to the conditions, content, and the overall system used for learning.

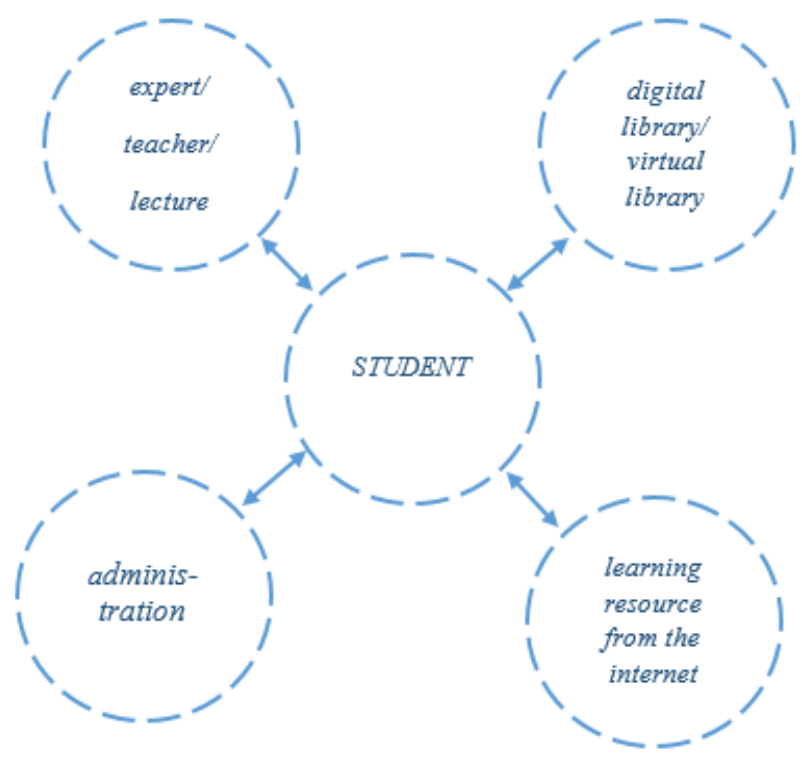

Fig. 1: Illustration of e-learning in learning [7]

From Figure 1, it can be explained that e-learning can be used as an electronic technology service that utilizes the superiority of computers, and still uses self-learning material stored on the server so that it can be accessed by all elements involved in learning, elearning can also take advantage of learning schedules, curriculum, the results of learning progress and things that are tied to the administration of education can be seen on a computer. Elearning facilitates interaction between students and subject matter. Likewise, the interaction between students and lecturers / teachers / instructors / experts or between fellow students. Students can share information or opinions about various matters relating to learning or development needs. Experts / lecturers / instructors can place learning materials and tasks that must be done by students in certain places on the web to be accessed by students.

The rapid development of information technology requires a concept and mechanism of information technology-based teaching and learning. E-learning is the main alternative choice in 
overcoming several problems that arise from the implementation of conventional education, along with the development of the internet that maintains the connectedness of each individual in the global network [12]. Learning methods with the concept of elearning can be an effective and efficient alternative choice in supporting the learning system by using interactive multimedia content as learning. Here are the characteristics of e-learning: (1) Utilizing electronic technology services, where educators and students, students and others or teachers and fellow teachers can communicate with relative ease without being limited by protocol matters; (2) Utilizing the advantages of digital media and computer networks; (3) Using self-teaching materials is stored on a computer, so that it can be accessed by teachers and students anytime and anywhere if they need it; (4) Utilizing the learning schedule, curriculum, progress of learning and matters relating to the administration of education can be seen at any time on the computer

\subsection{Vocational Education}

According to [13] that vocational education is closely related to the skills (skills) to use tools or machines, vocational education is identified with the assumption of dichotomy, namely common knowledge of opponents with special knowledge, or in the sense that education is explained in theory is different from education that is applied directly to practice. Understanding of opposing concepts with understanding of reproductive abilities.

In [14] states that vocational education is education that prepares individuals to enter the workforce then in the learning process related to practicum and mastery of competency techniques. This statement is supported by [15] opinion namely "The purpose of Vocational Education and Training (VET) is to provide the labor market with sub-professional levels", which can be explained that the meaning of the statement is that vocational education aims to provide employment with sub-professional level

\section{Methodology}

Research is a study of literature studies by examining several journals that are relevant to web based learning. The results of various literature reviews will be used to analyze the use of web based learning as a 21 st century learning model for vocational education

\section{Results and Discussion}

\subsection{Preparation and Development of Infrastructure and Web Based Learning Systems}

Infrastructure development and web based learning systems are carried out in stages. Like providing computers connected to each department that will be used by lecturers/teachers/experts. It would be better if it was provided to each of the related spaces, such as in the library, administration, all the heads of departments/concentrations, and the lecturer/teacher room. [16] According to [17], following are the stages of preparation and development of web based learning:

1. Designing web based learning and application program selection. This initial stage can take advantage of e-mail applications, mailing lists as interaction media. After the website that contains learning material is designed, then it can be uploaded on the existing server.

2. Development of teaching staff capacity. At this stage, the introduction of concept introduction and the web base learning system was held first, and intensive technical training was held.

3. Selection of subjects (courses), at this stage careful consideration is needed, what subjects can be considered eligible to be included in the concept of web base learning. There are several considerations in the selection of subjects including subjects that are considered difficult by students, this is indicated by the level of graduation of students and subjects who demand new skills, in the form of students' skills to express thoughts into written form or description.

4. Socialization of web based learning programs is carried out by providing information in a way that allows all students. At this stage also provided information about where students can access web base learning programs such as in computer labs, cooperating, etc.

\subsection{Benefits of Web Based Learning for Vocational Education}

In general, the implementation of web base learning can provide the following benefits: (1) an increase in productivity; (2) through web base learning time for travel can be reduced so that students / lecturers / teachers / experts will not be lost because of the travel activities that must be carried out to provide learning; (3) flexible and interactive, can be done from any location as long as he has a connection to the source of knowledge and interactivity made possible directly or indirectly; (4) the class does not prioritize physical form, everything can be used in internet applications; (5) web base learning programs can be implemented and updated quickly; (6) real time interactions such as chat, netmeeting or nonreal time can be created such as e-mail, mailing list; (7) can accommodate the entire learning process, starting from registration, material matching (matriculation), discussion and evaluation; (8) lecturers/teachers/experts can quickly add references to teaching materials that are case study, industry trends, and projections of technology in the future through various sources to increase participants' insight into their teaching materials [18]. Besides, the benefits in general, the use of web base learning can empower students and encourage responsibility for their learning, as stated by [19] that (1) students who carry out on-line learning activities can learn interactively and mutually linkages between their peers; (2) students who are busy or working who may not be able to take lessons regularly can be on time through the face-to-face learning process, therefore web base learning media is very effective to use; (3) students can get guidance and assistance from lecturers/ teachers/experts, tutors, resource persons, colleagues who are far apart; (4) learning materials or models will be more consistent, systematic and organized so as to make it easier for students to take lesson modules; (5) tracking and evaluating and administering student progress is more organized and easily obtained.

From the above statement supported by the opinion [20] that the use of computer-based media can improve students' understanding. To be more effective in its use, content must not be excessive, used in possible situations with many sources. In [21] states that multimedia use should only be used when students have low initial knowledge, when students have low motivation, and when multimedia is designed effectively.

\section{Conclusion}

E-learning is a learning process that is poured through internet technology. In addition, the principles of simple, personal, and fast need to be considered. To increase attractiveness, you can also use game theory. Therefore, learning principles and communication need to be designed like conventional learning. Here the need for the development of an e-learning model that is right for your needs.

Web base learning is learning that requires technological tools, especially information technology such as computers and internet access. In practice web base learning utilizes internet facilities as a medium for delivering information (material) learning such as websites, e-mail, mailing lists, and news groups. The planned use of web base learning technology has been proven to provide a significant contribution to the world of vocational education, 
despite the disadvantages and advantages of web base learning technology.

In implementing web base learning there are several factors that need to be considered such as supporting facilities and infrastructure, users (students as users and lecturers as material presenter), online material readiness and costs.

\section{References}

[1] Liputan6. (2017). Jumlah pengguna internet dunia sentuh 3,8 Miliyar. https://www.liputan6.com/tekno/read/3051109/jumlahpengguna-internet-dunia-sentuh-38-miliar

[2] Kompas.com. (2018). Jumlah pengguna internet Indonesia. https://tekno.kompas.com/read/2018/02/22/16453177/berapajumlah-pengguna-internet-indonesia.

[3] Surjono, H. D. (1998). Sistem ABC: Perangkat lunak untuk membuat program CAI. Jurnal PTK, 9(7), 35-38

[4] Rosenberg, R. (2009). Video conferencing in distance learning: A New Zealand schools' perspective. Journal of Distance Learning, 2009, 13(1), 91-107.

[5] Felix, U. (2001). A multivariate analysis of students' experience of web based learning. Australasian Journal of Educational Technology, 17(1), 21-36.

[6] Surjono, H. D. (2015). The effects of multimedia and learning style on student achievement in online electronics course. Turkish Online Journal of Educational Technology, 14(1), 116-122.

[7] Zakir, S. (2015). Local web based learning: Media pembelajaran alternatif. Proceedings of the ASEAN Comparative Education Research Network Conference, pp. 1107-1120.

[8] Naidu, S. (2003). E-learning: A guidebook of principles, procedures and practices. Commonwealth Educational Media Centre for Asia.

[9] Trilling, B., \& Fadel, C. (2009). 21st century skills: Learning for life in our times. John Wiley and Sons.

[10] Bello, O. W., Ehira, D. N., Ayeni, J. K., Faruk, N., \& Balogun, N. A. (2014). Towards the design of a synchronous virtual learning system. Journal of Informatics and Communication Technology, 2(2), 59-74.

[11] Hardyanto, R H. (2016). Pengembangan dan implementasi elearning menggunakan Moodle dan Vicon untuk pelajaran pemrograman web di SMK. Jurnal Pendidikan Vokasi, 6(1), 4353.

[12] Minghat, A. D., Yasin, R. M., Subari, K., \& Noordina, M. K. (2013). Strategi kelasterian pembangunan pendidikan teknikal dan vokasional (PTV). Proceedings of the 2nd International Seminar on Quality and Affordable Education, pp. 493-504.

[13] Pavlova, M. (2009). Technology and vocational education for suistanable development. Springer.

[14] Nasution, T. (2015). Penerapan metode web based learning sebagai solusi pendidikan yang efektif dan efisien. Jurnal TIMES, 4(2), 49-52.

[15] Clarke, L., \& Winch, C. (2007). Vocational education International approaches, developments and systems. Routledge.

[16] Rahman, A. A., Hanafi, M. N. Mukhtar, I. M., \& ahamad, J. (2013). Assessment practices for competency based education and training in vocational college, Malaysia. Procedia-Social and Behavioral Sciences, 112, 1070-1076.

[17] Khan, B. H. (1997). Web based instruction. Educational Technology Publications.

[18] White, K. W. (2000). The online teaching guide. Allyn and Bacon.

[19] Davidson-Shivers, G. V., \& Rasmussen, K. L. (2006). Web-based learning. Pearson Prentice Hall.

[20] Surjono, H. D. (2011). The design of adaptive e-learning system based on student's learning styles. International Journal of Computer Science and Information Technologies, 5(2), 23502353

[21] Singh, V. K. (2003). Does multimedia really improve learning effectiveness? Asia Pacific Conference on Education, Reenvisioning Education: Innovation and Diversity. 